\author{
(online) $=$ ISSN $2285-3642$ \\ ISSN-L = $2285-3642$ \\ Journal of Economic Development, Environment and People \\ Volume 4, Issue 4, 2015 \\ URL: http://jedep.spiruharet.ro \\ e-mail: office jedep@spiruharet.ro
}

\title{
Estimating the Outdoor Recreational Value of Chitgar Forestial Park of Tehran with the Use of Contingent Valuation Method (CV)
}

\author{
Majid Kholuzini Sharahi ${ }^{1}$, Mohamad Hosein Mohamadi ${ }^{2}$, Azam Abedini ${ }^{3}$ \\ ${ }^{1,3}$ University of Allame Tabataei, Tehran \\ ${ }^{2}$ University of Ashrafi Isfahani, Isfahan
}

\begin{abstract}
Among issues related to the environment, one of the most important issues is pricing the environment. In the present study, the outdoor recreational value of Chitgar Jungle Park of Tehran and its visitors' willingness to pay per visit (WTP) were estimated by using Contingent Valuation method (CV) and 140 questionnaires based on dichotomous choice. The results revealed that 30 percent of the surveyed people were willing to pay an entrance fee and the mean willingness to pay for each visitor was estimated at 3076 Rials and its total annual recreational value was estimated at 5 billion Rials. Among the effective variables on individuals' visit of this park, recommendation, income, per-visit cost, family size, and visits during a year were 1\% significant; park facilities and quality were 5\% significant; and the visitors' use of personal vehicles, education, type of house, as well as job were $10 \%$ significant.
\end{abstract}

Keywords: Environment, Contingent Valuation (CV), Willingness to pay, Logit model

JEL Codes: Q51, C25, Q29

\section{Introduction}

Jungle ecosystems have a number of tangible and intangible economic benefits for human beings, which can be classified into four groups, namely, direct values, indirect values, select values, and existence values. Direct values are referred to direct use of resources which, in the case of jungles, include not only timber trade but also resin, sap and aliments such as walnuts, hazelnuts and Recreational and tourist incomes are also direct values. Indirect values are referred to the benefits which people can gain indirectly. Environmental and ecological benefits such as absorption of carbon dioxide, preventing soil erosion, controlling floods, modifying the weather and biodiversity are examples of indirect values. Select values include all direct and indirect values which are realizable in future or the values attributed to the ability to use the products and services in future such as future medical and agricultural discoveries concerning plants and new ecological resources. Existence values include the intrinsic value of a resource such as jungle and the value which people consider solely for the existence of that resource and its environmental activities. Therefore, recreational and tourist values are direct values of jungles and parks and include recreation, spending leisure time, walking and aesthetics (Hamid Amir Nejad, 1385 (2006)). 


\author{
(online) = ISSN $2285-3642$ \\ ISSN-L = $2285-3642$ \\ Journal of Economic Development, Environment and People \\ Volume 4, Issue 4, 2015 \\ URL: http://jedep.spiruharet.ro \\ e-mail: office jedep@spiruharet.ro
}

\title{
2. Statement of the Problem
}

Contributions Capitals related to nature and environments are very important in sustainable development and so far many attempts have been made to estimate and appraise the financial value of ecosystems' services. On a micro level, researches regarding valuation will lead us to the data related to the ecosystem's function and its pivotal role in human welfare; moreover on a macro level, ecosystem valuation can participate in creating and modifying the indices of welfare and sustainable development (Howarth \& Farber, 2002).

Most of environmental products and services can be placed in public goods category because they frequently have no price tag and there are doubts about their actual price (Karimzadegan, 1372 (1993)).

Valuation can be defined as the process of evaluating a particular object or function. The valuation of non-market functions and services of environment is of great importance due to many reasons such as exploring environmental and ecological benefits by humans, presenting the environmental issues to authorities, making connection between economical policies and natural incomes, measuring the role and importance of environmental resources in human welfare and sustainable development, modifying national accounts such as GDP, as well as preventing the destruction and overuse of natural resources (Vaze 1998, Ashim 2000, Guo et al. 2001).

In this study, we attempt to estimate the outdoor recreational value of Chitgar Jungle Park of Tehran by using contingent valuation method. We will determine the factors influencing the payers' willingness to visit as well.

\section{Theoretical Pricing Model}

The value of natural resources in environmental economics includes use value and non-use value. The use value is the value gained from using products and services and is related to consumer's surplus in recreational use of natural resources. The use value includes the following: 1) Current use value, which is gained from the present use; 2) Expected use value, which is related to the use value in near future; 3 ) Probable use value, which is employed for use value in far future. The non-use value is the utility gained while we have not actually used any products. It includes existence value, friendship value, heritage value, and preservation value. In addition, urban parks and green areas have several more functions as well. Nature always attracts people with its beauties. Green vegetation with fountains, resorts and purlieu is a proper means to lower stress and is a good opportunity for exchanging ideas among families. Now the main question is that how valuable the environment is for people and how much they are willing to pay to enter parks. Although natural attractions have remarkable benefits, they have limited financial resources. Charging entrance fee can be the best method to raise funds and there are two views regarding this issue:

1. Public-good View: In this view, income taxes are the only valid resource for raising funds because they are national and belong to every individual and maximize the welfare of all society; therefore, they should be free for everyone.

2. Users' payments View: The supporters of this view believe that profits belong to those who use the environment because a small population of general public constantly visits these areas. Therefore, charging entrance fee is a suitable policy and can be a way of making money from international tourists because they pay taxes where they come from. It is stated that this policy may be detrimental to the low-income 


\author{
(online) = ISSN $2285-3642$ \\ ISSN-L = $2285-3642$ \\ Journal of Economic Development, Environment and People \\ Volume 4, Issue 4, 2015 \\ URL: http://jedep.spiruharet.ro \\ e-mail: office jedep@spiruharet.ro
}

parts of the society and may decrease their use, but the answer is that with various entrance fees, this problem can be resolved to some extent.

Evaluating environmental goods is highly difficult because they have some of the public goods features such as being indivisible and not possess-able; therefore, they have no market and it is difficult to price them because when there is no market, allocations are not effective..

Demand function: In consumers' preferences is one of the basics of economics and the most usual method is demand function. The demand function shows the amount of commodity which a person with a certain income and by considering a certain range of prices demands. In fact, demand graph is one of the methods to summarize the importance of a product for a person; moreover by summarizing a person's preferences for a product, we can calculate its total consumption via demand curve. There are a number of problems in calculating demand function of environmental goods, and the main problem is lack of market for environmental goods. However, we know that people value environmental goods and are ready to pay some money to preserve them. Therefore, we use the indirect method to calculate the demand function.

\title{
4. Indirect Methods for Calculating Environmental Goods Demand:
}

There are two simple methods: 1) Revealed preference method; 2) Expressed preference method.

1. Revealed preference method: This method is based on people's actual preferences in the market and extracting the demand through exchanging money and goods.

2. Expressed preference method: It refers to expressing the use value or non-use value of environmental goods by people. In this method, no goods is exchanged and choices are hypothetical and it includes asking people questions.

Revealed preference includes two methods:

1. Hedonic method: In case of lack of market, the value of an environmental phenomenon is calculated according to the market value of similar goods. Any difference between prices is the result of environmental conditions difference which affects the quality of products. For example, if other conditions are identical, it is expected that a property in an area with good weather has a higher price compared to a property in an area with polluted weather.

2. Household production method: Consumers combine private goods with environmental goods and use them so that they can obtain other desired goods. For example, if a house is located near a street and noise pollution annoys the households, it can be reduced by double-glazing the windows; in other words, we can obtain environmental goods (peace and quiet) by spending money on a private goods. Therefore, the expense that the family undergoes is equal to the value of environmental goods.

The approach of expressed preference is dominant method of contingent valuation, that is, if there was a market, how much a person would pay for environmental goods. In other words, the consumer is asked how much he is willing to pay to obtain environmental goods, or how much he is willing to receive to decide not to use environmental goods. In fact, this method is based on a hypothetical market which is used as an indirect method of demand estimation for environmental valuations. 


\author{
(online) = ISSN $2285-3642$ \\ ISSN-L = $2285-3642$ \\ Journal of Economic Development, Environment and People \\ Volume 4, Issue 4, 2015 \\ URL: http://jedep.spiruharet.ro \\ e-mail: office jedep@spiruharet.ro
}

\title{
5. Methods for Estimating Outdoor Recreational Value of Jungle Parks and Choosing Contingent Valuation Method
}

Travel cost method: This method is based on the evaluation of environmental sceneries and transportation projects, that is, if an individual goes to a recreational location with the entrance fee of zero, the minimum cost for that place equals to his access cost and we must add other costs to it as well. Since it varies from one person to another, we can find a demand function for that recreational place and by using that function we can calculate the consumer surplus as well. This method has some flaws as well; for instance: 1) It can only be used for certain locations (recreational attractions). 2) If an individual intends to visit several recreational places, it will be difficult to separate them. 3) The use of some places is seasonal and this method is not a short-term method and the valuation may become biased. 4) Since the distance between the place and people's houses varies, the value estimation may become unreal.

Considering these limitations, contingent valuation method is frequently used. The contingent valuation method was primarily proposed in theory by S.V. Ciriacy-Wantrup (1947) and the first practical application of the method was applied in 1963 by Davis. This method includes surveying people directly regarding how much they value recreational or relaxing utilities. In fact, the researcher's goal is to influence the degree of people's willingness to pay by explaining market conditions in a hypothetical market so that he can inform people why financial resources are necessary and in what parts, they will be spent. This method can be applied via two approaches:

1. Experimental approach based on simulation

2. Collecting data through questionnaires or survey techniques.

Willingness to pay: The willingness to pay is a criterion for measuring a consumer's benefits from a change in price or amount of a merchandisewhich most of it is related to outdoor recreational utilities and natural attractions since a natural attraction with free access is a non-market goods. The willingness to pay (WTP) is the amount a person would be willing to pay in order to obtain an increase in his welfare or to avoid a decrease in his welfare. Estimation of WTP for natural attractions is the basis of social cost-benefit analysis which is based on Kaldor-Hicks criterion. In general, when there is no market, the ultimate willingness to pay for a goods or service is considered as its shadow price, which depends on distribution of income, wealth and resource allocation in the entire economy and society.

\section{Effective Factors on Willingness to Pay}

The value that people consider for visiting and using recreational areas belongs to these places and people can show that by the amount of money they are willing to pay. The difference in people's willingness to pay comes from demographical, economical, social, and other related factors.

According to Ajzen Model (1966), behavioral variables such as willingness to pay are a function of attitudes influenced by individuals' behavioral experiences. The findings of Manfredo and Ker (1991) indicate that people's past behavior is effective in willingness to pay. Knetsch (1984) showed that the demand for natural attractions with unique sceneries and remarkable recreational facilities is inelastic to price. 


\author{
(online) = ISSN $2285-3642$ \\ ISSN-L = $2285-3642$ \\ Journal of Economic Development, Environment and People \\ Volume 4, Issue 4, 2015 \\ URL: http://jedep.spiruharet.ro \\ e-mail: office jedep@spiruharet.ro
}

Variables such as income, visitor's overall satisfaction, using a guide while visiting, group tour, and economic-political stability have positive influence and the number of previous visits has negative influence on willingness to pay (Reynisdottir \& Song \& Ayrusa, 2008).

\title{
6.1. Advantages and Ddisadvantages of this Method
}

Criticism: The results of surveys are based on hypothetical assumptions; therefore, they are biased (Hausman, 1993), which can be as a result of choosing incorrect samples, low ratio of answers, and other related factors.

According to Arrow (1993), the identified bias in this method is: Design bias, which includes the subjectivity for setting the asking price with payment tools. Operational bias is referred to lack of knowledge concerning the goods which we will evaluate. Hypothetical bias suggests that the force to pay may not really happen in near future. Strategic bias recommends that people's willingness does not reveal their actual preference, that is, general public tend to influence the future pay by overstating or understating their real willingness to pay. In fact, the aforementioned bias is categorized in four main categories.

Hypothetical bias: The main reason for hypothetical bias, according to researchers, is that respondents are asked to express their willingness to pay for changes. Moreover, they are frequently hypothetical and the responses may be unreliable. The best studies are those closer to reality.

Information bias: It originates from the information provided to the respondents in such a way that the primary prices offered to people are effective in forming their paying. In payment vehicle bias, it is stated that reasonable behavior can explain the reason for the relation between willingness to pay and payment tools. Evidence suggests that the amount of asking price can be sensitive to payment method.

Strategic bias: it is caused by respondent's personal tendency to influence the results of the study. This bias is one of the clear examples of hitchhiking phenomenon in which the respondent, while answering the question, considers if he will really be asked to pay the asking price in the future; subsequently, he expresses the amount of his willingness to pay based on that problem.

Although bias cannot be completely eliminated, careful design of the questionnaire and statistical process of survey can control the bias of respondents and minimize them.

This method has several advantages such as widespread use, reliable valuation of travels without considering if the aforementioned place is the first destination or the second, ability to estimate both use value and non-use value and the possibility to study the surveys which lack market data. These have made this technique a highly practical tool in economic analyses.

Payment vehicle: It is very important to choose an appropriate payment vehicle because the type of payment vehicle can greatly affect the results. In general, the common vehicle for recreational values charges an entrance fee and other vehicles pertaining to preservation and security are usually in the forms of taxes, entrance fees, or cash donations.

The most important ways of collecting data are: Direct interviews, questionnaires and telephone surveys. The direct interviews for being expensive, surveying via letters for the low number of received responses, and telephone surveys for limiting the information are not usually used. In most surveys pertaining to contingent, valuation questionnaires are used. According to aforementioned points, in order 


\author{
(online) = ISSN $2285-3642$ \\ ISSN-L = $2285-3642$ \\ Journal of Economic Development, Environment and People \\ Volume 4, Issue 4, 2015 \\ URL: http://jedep.spiruharet.ro \\ e-mail: office jedep@spiruharet.ro
}

to let respondents know about the hypothetical market, a DDC questionnaire was designed for interviews and finding out visitors' WTP for estimating the outdoor recreational value of Chitgar jungle park of Tehran. This questionnaire consists of two parts. The first part includes the socio-economic status of respondents in a way that it surveys regarding their education, number of family members, income and other characteristics. The second part is related to their willingness to pay. In this part, three offers of 3000 Rials, 5000 Rials and 7000 Rials, which were obtained by using Gauss software, were prepared in the form of three related questions. In the first question, we asked about the average price (5000 Rials) which by this means: Chitgar Park has provided an opportunity of recreation and relaxation for you; are you willing to pay 5000 Rials as an entrance fee to use them? In case of negative answers, the lower price (3000 Rials) was asked and in case of positive answer, the higher price (7000 Rials) was asked. The respondents could respond either positive or negative answer and if they were not willing to pay anything, they were able to give no answer. To estimate the adequate number of samples, Cochran Formula and simple random sampling were used in this study. The adequate number of samples was obtained based on analysis of mean and variance of the statistical population resulted from filling 30 questionnaires. At the end, 145 questionnaires were filled and 19 of them were placed aside because they were incomplete or the questions were not understood by respondents. The other 126 questionnaires were analyzed. Questionnaires were completed in two weeks in summer 1391 (summer 2012).

\title{
7. Methodology
}

In our methodology for estimating the willingness to pay, we assume that the person accepts the offered entrance fee provided that he maximizes his utility (John Asafu, 2008). The utility that a person gains by using environmental resources is more than the time that they do not use environmental resources.

$$
U(1, Y-A ; S)+\varepsilon_{-}(1) \geq U(0, Y ; S)+\varepsilon \_0
$$

The difference of utility because of using environmental resources is calculated as follows (John Asafu, 2008):

$$
\mathrm{U}=\mathrm{U}(1, \mathrm{Y}-\mathrm{A} ; \mathrm{S})-\mathrm{U}(0, \mathrm{Y} ; \mathrm{S})+\left(\varepsilon_{-} 1-\varepsilon_{-} \_\right) \Delta
$$

1 represents acceptance of paying entrance fee, 0 is designated as refusal of paying entrance fee. $A$ is assigned as the offered entrance fee, $Y$ stands for the person's income and $S$ is other characteristics. $\varepsilon_{-} 1$ \and $\varepsilon \rrbracket_{-} 0$ are random variables with the mean of zero which have been distributed equally and independently.

$\left(P_{-} \mathrm{i}\right)$, the possibility that the person will accept the price $A$, is as follows (based on logit model). It is an indirect utility that the visitor gains.

$$
P_{i}=F_{\eta}(\Delta U)=\frac{1}{1+\exp (-\Delta U)}=\frac{1}{1+\exp \{-(\alpha-\beta A+\gamma Y+\theta S)\}}
$$

$\boldsymbol{F}_{\boldsymbol{\eta}}(\Delta \boldsymbol{U}) \boldsymbol{I}$ represents a cumulative distribution function with a standard logistic difference.

$\mathrm{Y}$ stands for the person's income, $\mathrm{A}$ is the offered price and $\mathrm{S}$ is other characteristics. 


\author{
(online) = ISSN $2285-3642$ \\ ISSN-L = $2285-3642$ \\ Journal of Economic Development, Environment and People \\ Volume 4, Issue 4, 2015 \\ URL: http://jedep.spiruharet.ro \\ e-mail: office jedep@spiruharet.ro
}

\title{
7.1. Introducing Chitgar Park
}

Chitgar Park, with an area of 950 hectares, has always been an attractive resort for Tehran's residents to spend their leisure time. However, due to different problems including lack of appropriate recreational services and security, its permanent use has not been possible. Geographically, the park is located between Tehran and Karaj and it is surrounded by small towns. From south, it is limited to Tehran-Karaj highway and railway and from north, it is limited to Resalat highway and from west, it is limited to Peykan Shahr town and the Botanical Garden. It is predicted that the foresight of a central lake in the reorganization plan of Zone 22 of Tehran, with an area of about 355 hectares (the lake basin is less than 100 hectares) and capacity of 35 million $\mathrm{m} 2$ of water, located adjacent to Chitgar Jungle Park can make it the largest recreational facility in Tehran. The land of park has many ups and downs; therefore, it has many steep slopes ranging from $0 \%$ to $80 \%$.The park is mainly stretched from east to west and the ups and downs are mostly formed by small hills. Chitgar water course divides the park into western and eastern parts. The eastern part has an area of about 253 hectares and the western parts covers an area of nearly 658 hectares. The lowest and highest altitudes of the park are respectively 1225 and 1313 meters (the difference between highest and lowest points is 88 meters). The trees covering the park include an area of about 734 hectares. Approximately, 53 percent of these trees are acicular-leaved trees. In total, acicularleaved trees cover about 390 hectares of the park (about $48 \%$ of the park's total area). Broad-leaved trees cover 47 percent of the park.

The current facilities of Chitgar Park include cultural-sports complex, playgrounds, conference hall, storehouse, bicycle station and cycling track, fire station, restaurants and cafes, office buildings, parking, gazebos and tents.

Most of these facilities are located in the eastern part of the park and the western part has fewer facilities and is remained intact and wild.

\section{Review of Literature}

Many efforts have been made to estimate the amount of benefits gained from recreational forest and national parks. Such activities are an important part of benefit-cost analysis for management plans of jungle parks. In addition, a number of researches have been made regarding environmental preservation using contingent valuation method. The outdoor recreational value of Madagascar Jungles was estimated $\$ 360$ to $\$ 468$ using travel cost method (Maille\& Menderlsohn 1991). The value of jungles of Montana State of America, according to contingent valuation method, was $\$ 108$ for each travel and for eastern jungles of America, this amount was $\$ 10.43$ a year for each household (Krieger, 2001). The outdoor recreational value for five Korean national parks using CV method was an average of $\$ 10.45$ a year for each household (Lee Shan, 2002). Echeverria, et al. (1995) estimated the existence value of Costa Rican jungles $\$ 238$ per hectare a year. Tomas, et al. (1997), using CV method, found out that people were willing to pay between $\$ 5$ to $\$ 325$ a year in the United States of America in order to protect groundwater from chemical pollutants. Pajiola (2001), using CV method, estimated that locals and tourists were willing to pay $\$ 170$ and $\$ 70$, respectively in order to repair the Roman Palace in the ancient city of Split, Croatia. Togrido, et al. (2006) estimated visitors' WTP for Alonnisos Marine Park, Greece 120 and 30 BWP for locals and tourists, respectively. Costanza, et al. (1997) studied the total value of environmental and ecological services of 17 different ecosystems around the world and reported the outdoor recreational value of $\$ 112$ for tropical 


\author{
(online) $=$ ISSN $2285-3642$ \\ ISSN-L = $2285-3642$ \\ Journal of Economic Development, Environment and People \\ Volume 4, Issue 4, 2015 \\ URL: http://jedep.spiruharet.ro \\ e-mail: office jedep@spiruharet.ro
}

jungles as well as $\$ 36$ per hectare for temperate jungles. The outdoor recreational value of Malaysian jungles, using CV method, was estimated at $\$ 740$ per hectare. Amigues, et al. (2002) estimated the preservation value of Garonne river bank ecosystem in France, using CV method with Tobit linear model, semi-logarithmic model and Heckman two-stage model respectively at $67 \mathrm{FF}, 66.13 \mathrm{FF}$ and $133 \mathrm{FF}$. Whitehead and Finney (2003) valued the North CarolinaCoast, US, using CV method. The mean WTP for each visitor was $\$ 36$ and the annual benefit gained from historical shipwreck park was estimated at 1.75 million dollars (this coast has about 5000 shipwrecks).

Several studies in Iran that have used CV method are as follows: For the first time, the outdoor recreational value of Sisangan park was studied in 1353 (1974) using TC method and was estimated at 8960 Rials (Bakh shaei, 1353(1974)).

The value of Northern jungles of Iran is $\$ 2.51$ for each household and the annual value is $\$ 30.13$ (Amir Nejad, Khalilian, Osareh and Ahmadian, 2006). Asgari and Mehregan (1380 (2001)) estimated the WTP for historical Ganj Nameh in Hamedan, Iran, 1560 Rials per visit, using CV method. Mowlayi et al. (1380 (2001)), using CV method, showed that the WTP for preservation of Arasbaran jungle ecosystem was 112.52 Rials for each household a year. Dashti and Sohrabi (1387 (2008)) estimated the WTP for Nabovat Park in Karaj, Iran, at 3300 Rials for each visit, using CV method. The mean WTP for tourist value of Golestan national park was estimated at 3520 Rials per visit. The annual tourist value of this park was estimated at 1.96 million Rials per hectare and its total tourist value at 18 billion Rials (Amir Nejad, 1384(2005)).

Emami and Ghazi (1386 (2006)) estimated the mean WTP for Saeei Park of Tehran at 1840 Rials per visit, its monthly recreational value at 220 million Rials and its total annual recreational value at 2.7 billion Rials.

Zahra Tavakoli in her Master's thesis at Tehran University estimated the mean WTP for Chitgar Park 419.7 Rials per visit, using CV method. The independent variables of age, family size, number of previous visits, the offered price, income, gender and visitors' satisfaction were significant and the independent variable of education was negatively significant in this study, which is against economic theories. In the present study, using a different questionnaire, we found out that the independent variables of using personal vehicles, cost of visit, education, number of family members, park facilities, owning a house, income, visitors' opinion about park quality, average annual visits of park, job, and the offered price are significant.

\title{
9. Results and Discussion
}

To estimate the value of park, those visitors were surveyed who were financially independent; therefore, at the beginning of the questionnaire, we mentioned that we needed those who had independent income and free will.

Various questions were asked in this questionnaire. The variables are as follows: age, gender, education, membership in environmentalist organizations, marital status, number of family members, income, using personal vehicle, estimating the cost of visit, travel duration, time spent in the park, number of annual visits, environmental quality of park (choosing from 0 to 100), current park facilities (choosing from 0 to 100), and type of housing. 


\author{
(online) $=$ ISSN $2285-3642$ \\ ISSN-L = 2285 - 3642 \\ Journal of Economic Development, Environment and People \\ Volume 4, Issue 4, 2015 \\ URL: http://jedep.spiruharet.ro \\ e-mail: office jedep@spiruharet.ro
}

Table 1: Distribution of visitors' jobs

\begin{tabular}{|l|l|l|l|l|l|l|l|l|}
\hline & employee & teacher & $\begin{array}{l}\text { Self- } \\
\text { employed }\end{array}$ & student & Housewife/husband & worker & retired & total \\
\hline number & 37 & 6 & 33 & 27 & 13 & 7 & 3 & 126 \\
\hline percentage & 29.37 & 4.76 & 26.19 & 21.43 & 10.32 & 5.56 & 2.38 & 100 \\
\hline
\end{tabular}

Table 2: Distribution of visitors' education

\begin{tabular}{|l|l|l|l|l|l|l|}
\hline & Doctorate & Master's & Bachelor's & Associate's & $\begin{array}{l}\text { Diploma } \\
\text { and under }\end{array}$ & Total \\
\hline number & 0 & 12 & 43 & 26 & 45 & 126 \\
\hline percentage & 0 & 9.52 & 34.13 & 20.63 & 35.71 & 100 \\
\hline
\end{tabular}

Seventy of respondents (55.56\%) were men and 56 of them (44.44\%) were women. Eighty eight people $(69.84 \%)$ were not willing to pay an entrance fee and 38 people $(30.16 \%)$ were willing to pay an entrance fee.

Twenty five of respondents accepted the 5000-Rial entrance fee. Six people were willing to pay the 7000-Rial entrance fee after they had accepted the 5000-Rial entrance fee. Seven individuals did not accept the 5000-Rial entrance fee but were willing to pay 3000 Rials as an entrance fee. The logit model results, after elimination of insignificant variables, are shown in table 4.

Table 3: The logit model results for Chitgar Park, after elimination of insignificant variables

\begin{tabular}{|l|l|l|l|}
\hline variable & coefficient & t-statistic & Significance \\
\hline Constant factor & -9.881973 & -2.322780 & 0.0202 \\
\hline Vehicle & 2.480777 & 1.740382 & 0.0818 \\
\hline Cost & -0.141554 & -2.608796 & 0.0091 \\
\hline Education & -0.939745 & -1.710225 & 0.0872 \\
\hline $\begin{array}{l}\text { Number of family } \\
\text { members }\end{array}$ & -1.522711 & -3.001174 & 0.0027 \\
\hline Facilities & 0.084020 & 2.544638 & 0.0109 \\
\hline Housing & 2.302760 & 1.849446 & 0.0644 \\
\hline Income & 0.008193 & 2.863980 & 0.0042 \\
\hline
\end{tabular}




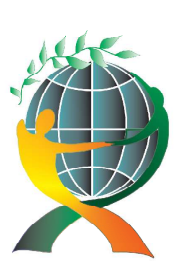

\author{
(online) $=$ ISSN $2285-3642$ \\ ISSN-L = $2285-3642$ \\ Journal of Economic Development, Environment and People \\ Volume 4, Issue 4, 2015
}

URL: $\underline{\text { http://jedep.spiruharet.ro }}$

e-mail: office jedep@spiruharet.ro

\begin{tabular}{|l|l|l|l|}
\hline Quality & 0.071872 & 2.384186 & 0.0171 \\
\hline Visits & 0.271852 & 2.855010 & 0.0043 \\
\hline Job & -0.563401 & -1.911998 & 0.0559 \\
\hline Offer & -0.0021376 & -3.234544 & 0.0012 \\
\hline $\begin{array}{l}\text { Mc Fadden R-squared=0.679329 prob(LRstatistic)=0.000000 } \\
\text { LR statistic:93.31836 } \\
\text { Log likelihood=-22.02508 }\end{array}$
\end{tabular}

Reviewing the coefficients shows that the most important explanatory variable, which is entrance fee offer, is at $1 \%$ significance level and it is minus which means the more the entrance fee increases, the less its WTP will be. The coefficient of income variable is at $1 \%$ significance level and it is positive, which means the more the income, the more the possibility of willingness to pay of an entrance fee. The cost variable is at $1 \%$ significance level, which means the more the travel cost, the less they are willing to pay an entrance fee.

The number of visits during a year is at $1 \%$ significance level and has a positive effect. The number of family members is at $1 \%$ significance level and has a negative effect. The park facilities and quality have a positive effect at $5 \%$ significance level. The type of housing is at $10 \%$ significance level, which means those who own a house are willing to pay a higher entrance fee. The vehicle variable is at $10 \%$ significance level and has a positive effect. Job has a negative effect and shows that the retired and workers are willing to pay a lower entrance fee and it is at $10 \%$ significance level. All these are in compliance with the theory.

The education variable is at $10 \%$ significance level and has a negative effect which is due to the way of entering the variables into the software, because we attributed 1 to doctorate, 2 to Master's and so on. That is, as the education decreases, the WTP also decreases, and this is in agreement with economic theories.

\title{
9.1. Calculating the WTP and the total annual outdoor recreational value of the park
}

There are three ways for calculating the amount of WTP: 1 ) the mean WTP, in which the numerical integration over the domain of zero to infinity is used in order to calculate E (WTP). 2.) The mean of total WTP, which they use the integration over the domain of $-\infty$ to+ $\infty$ for calculating $E$ (WTP). 3) The mean of approximate WTP, in which the numerical integration over the domain of zero and maximum offer (A)is used in order to calculate E (WTP). Among these approaches, the third one is the best because it retains the consistency and agreement of limitations with the theory, statistical efficiency, as well as integrability.

$$
\mathrm{E}(\mathrm{WTP})=\int_{0}^{M A X \cdot A} F_{\eta}(\Delta U) d A=\int_{0}^{M A X \cdot A}\left(\frac{1}{1+\exp \left\{-\left(\alpha^{*}+\beta A\right)\right\}}\right) d A
$$

E (WTP) is the expected amount of WTP and $\alpha^{\wedge *}$ is the adjusted $y$-intercept that other effective factors have been added to $\alpha^{\wedge *}$. 


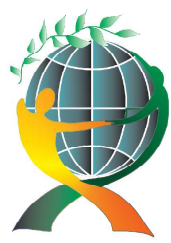

\author{
(online) $=$ ISSN $2285-3642$ \\ ISSN-L = 2285 - 3642 \\ Journal of Economic Development, Environment and People \\ Volume 4, Issue 4, 2015
}

URL: http://jedep.spiruharet.ro

e-mail: office jedep@spiruharet.ro

$E(W T P)=\int 0^{\wedge} 70001 / 1 /(1+\exp \{-(6.459-0.0021 A)\}) d A=3076.334$

An amount of 3076.334 is obtained for each visit of the park.

Based on the interviews with officials concerning the number of visits to the park, the following statistics was received. The average number of visits on weekdays was 5500; on Thursdays, it was 9000 people; on Fridays, it was 12000 people and on national Nature Day (April 2nd), it was 250,000 people. Therefore, the number of total annual visits is 1,654,500 individuals and the total outdoor recreational value is calculated through the following equation:

Total value of park $=$ the mean WTP * the number of total annual visits

Total value of park $=3076.334 * 1654500=5089794600$

Thus the total outdoor recreational value of the park is $507,327,442.05$.

\title{
10. Conclusion
}

In this research, we studied the outdoor recreational value of Chitgar Park and determined whether people were willing to pay an entrance fee. We used the CV method and dichotomous-choice questionnaires because people can choose their criteria based on monetary measures. Given that Iran is a developing country, only $30 \%$ of people are willing to pay an entrance fee. In this study, the mean WTP was 3076.334 Rials and its maximum amount was 7000 Rials. The total outdoor recreational value of the park was estimated at 5,089,794,600 Rials, which shows the value users allocate for the environment. The results reveal that the amount of entrance fee, income, number of visits during a year, number of family members and cost are the most influential factors on willingness to pay and they are at $1 \%$ significance level and park facilities and quality are the variables which are at $5 \%$ significance level. Using a personal vehicle, education, owning a house and job are the variables that are at $10 \%$ significance level. Since park quality and facilities are variables influential on accepting an entrance fee, we can attract more people to parks by creating suitable places for families and improving the facilities including public restrooms and playgrounds. Considering the air-pollution in Tehran, attracting more people to parks can be an effective step to increase users' psychological comfort and peace.

\section{References}

[1] Ajzen I,Brown TC,Rosenthal LH.Information bias in contingent valuation:effects of personal relevance, quality of information, and motivational orientation.Journal of Environmental ECONOMICS AND MANAGEMENT 1996;30;43-57.

[2] Amigues, j.,Boulatoff,C.andDesaigues, B. 2002. The benefits and costs of riparian analysis habitat preservation: a willingness to accept / willingness to pay contingent valuation approach.Ecological Economics.43(1):17-31.

[3] Amirnejad, H., Khalilian, S.and Assareh, M.H.2006.Estimating the existence value of north forests of Iran by using a contingent valuation method. Ecological Economics.58(4):665-675.

[4] Amirnejad, H.2007.Estimating the preservation value of Golestan National Park of Iran by using individuals willing to pay.Journal of Agricultural Economics.1(3):175-188

[5] Arrow,K.,R.Solow, R. Portney, E.Learner,R.Rander and H.Schuman.(1993).Report of NOAA Panel on contingent valuation: Report to the National oceanic and Atmospheric Administration.Federal Register,Vol.48,4601-4614. 


\author{
(online) $=$ ISSN $2285-3642$ \\ ISSN-L = 2285 - 3642 \\ Journal of Economic Development, Environment and People \\ Volume 4, Issue 4, 2015 \\ URL: http://jedep.spiruharet.ro \\ e-mail: office jedep@spiruharet.ro
}

[6] Asafu John-Adjaye and SoradaTapsuwan, "A Contingent Valuation Study of Scuba Diving Benefits:Case Study in Mu KO Similan Marine National Park,Thailand",Tourism Management,29(2008),1122-1130.

[7] Asgari,A.and Mehregan,N.2001.Estimating of Individuals willingness to pay of cultural- historic bequest using a contingent valuation method. AHamedanGanjname case study. Journal of Economical Researches,1(2):93-115.

[8] Ashim,G.B. 200. Green national accounting:Why and How? Environment and Development Economics.5(1):25-48.

[9] Bakh shaei, A.1353.Introduction of National parks and Forests.Tehran Universitypress.

[10] Dashti,GH .and Sohrabi, F .2009.Recreational value of Nabovat Park of Karaj based on contingent valuation.Journal of the Iranian Natural Resources.61(4):69-77.

[11] Echeverria, J., Hanrahan, M.and Solorzano, R.1995. Valuation of non-priced amenities provided by the biological resources within the monterverde cloud forest preserve, Costa rica. Ecological Economics.13:43-52.

[12] EmamiMeybodi, A., and Ghazi, M. 2008. Estimation of economic-recreational value of the Saee Park of Tehran, Iran by using the Contingent Valuation Method. Journal of Economic Research. 36: 187-220

[13] Guo, Z., Xiao, X. Gan , Y. and Zheng , Y.2001.Ecosystem functions, services and their values a case study in Xingshan country of china. Ecological Economics.38(1):141-145.

[14] Howarth, B.R., and S.Farber.2002.Accounting for the value of ecosystem services. Ecological Economics.41(3):421429.

[15] Knesth JL, Sinden JA.Willingness to pay and compensation demanded:experimental evidence of an unexpected disparity in measures of values.Quarterly Journal of Economics1984;99:570-21.

[16] Krieger, D. J. (2001). Economic Value of Forest Ecosystem Services: A review. The wilderness society, Washington, D.C.,U.S.A.

[17] Lee, C. \& Han,S (2002). Estimating the Use and Preservation Values of National Parks Tourism Resources Using a Contingent Valuation Method, Tourism Management,23:pp531-540.

[18] Maille, P.\& R. Mendelsohn, (1991).Valuing Ecotourism in Madagascar,New Haven:Yale school of forestry,Mimeo.

[19] Molaei, M., Yazdani, S. and Sharzehi,Gh.2009.Estimating preservation value of Arasbaran forest ecosystem using contingent valuation. Journal of Agricultural Economics. 3(2):37-64.

[20] Pagiola, S. 2001. Valuing the Benefits of investments in cultural heritage: The historic core of split. In Paper presented at the international conference on economic valuation of cultural heritage, Cagliari, 19-20.

[21] Tavakoli Kermani, Zahra. 2009. An Estimation of Economic_Recreational Value of Chitgar Forest Park, Using the Contingent Valuation Method, a thesis submitted to the Graduate Studies Office in particular fulfillment of the requirement for the degree of Master of Arts in Environmental Economics.

[22] Thomas, H. and Christopher, B. 1997. Conjonint analysis of groundwater protection programs. American Journal of Agricultural Economics.26(2):229-236.

[23] Togridou, A., Hovardas,T. and Pantis, J.D.2006.Determinantes of visitors' willingness to pay for the National Marine Park of Zakynthos, Greece.

[24] Vaze, P.1998.System of environment and economic accounting(SEEA).Chapter 13,London:ONS,UK.

[25] Whitehead, J. C and Finney, S.2003 .Willingness to pay for submerged maritime cultural resources. Journal of Cultural Economics.27 (4):231-240. 